\title{
EFEKTIVITAS DAN EFISIENSI MODAL KERJA DALAM MEMPENGARUHI PEROLEHAN RETURN ON ASSET PADA PERUSAHAAN SEMEN YANG TERDAFTAR DI BURSA EFEK INDONESIA
}

Oleh:

Alhidayatullah

Fakultas Ekonomi - Program Studi Manajemen Retail - Universitas Muhammadiyah Sukabumi E-mail : Alhidayatullah@ummi.ac.id

Antony

Fakultas Ekonomi - Program Studi Manajemen Retail - Universitas Muhammadiyah Sukabumi E-mail : Antony58@ummi.ac.id

\begin{tabular}{l}
\hline Article Info \\
\hline Article History: \\
Received $26-$ Jan- 2021 \\
Accepted $22-$ Feb - 2021 \\
Available Online \\
28 - Feb-2021
\end{tabular}

\begin{abstract}
This study aims to determine cash turnover, accounts receivable turnover, inventory turnover, working capital turnover in influencing return on assets (ROA) in cement companies listed on the Indonesia Stock Exchange for the period 2016 - 2019. This study uses an explanatory analysis method with a quantitative approach, namely a research method that intends to explain the position of the variable under study and the causal relationship between one variable and another through hypothesis testing and focuses on variable problems with concepts that have value and looking for relationships between these variables. Hypothesis test results show that cash turnover to ROA is tcount -1,204<ttable 2,365 and sig $t 0,268>0,05$, turnover of accounts receivable to ROA is calculated from tcount $0.078<$ ttable 2.365, and sig $t$ $0.940>0.05$, inventory turnover at ROA where the value of t count $-1.099<t$ table 2.365, and sig t 0.308>0.05, and the turnover of working capital to ROA, the calculation is $t$ count $0.628<t$ table 2.365 , and sig $t 0.550>0.05$, which explains that all independent variables have no significant effect on ROA. While cash turnover, accounts receivable turnover, inventory turnover, and working capital turnover together (simultaneously) do not have a significant effect on return on assets, the calculation results show Fcount 0.672 $<$ Ftable 4.120 and the significance is 0.632> 0.05. Based on the analysis of the coefficient of determination, the effect of cash turnover, accounts receivable turnover, inventory turnover, and working capital turnover on return on assets is $27.8 \%$, the remaining $72.2 \%$ is influenced by other factors not examined.
\end{abstract}

\section{Keyword :}

Cash Turnover, Account

Receivable Turnover,

Inventory Turnover,

Working Capital Turnover, and Return on Assets. 


\section{PENDAHULUAN}

Suatu perusahaan dalam pendiriannya, pada dasarnya harus memiliki faktor utama dan tujuan dari perusahaan tersebut. Faktor utama yang sangat penting yaitu adanya modal kerja yang optimal untuk menjalankan kegiatan operasional perusahaan, dimana tanpa adanya modal maka aktivitas perusahaan tidak akan berjalan. Modal merupakan kekayaan yang dimiliki oleh perusahaan yang tercermin pada aset lancar dan aset tetapnya. Sedangkan modal kerja merupakan aset lancar yang digunakan dalam kegiatan operasional perusahaan. Selain digunakan dalam operasional perusahaan sehari-hari, modal kerja juga dapat menunjukkan tingkat keamanan atau margin of safety para kreditur terutama kreditur jangka pendek. Dengan adanya modal kerja yang optimal akan membuat perusahaan beroperasi secara maksimal dan tidak akan mengalami kesulitan apabila adanya krisis atau kekacauan keuangan.

Pengelolaan modal kerja merupakan tanggung jawab setiap manajer atau pimpinan perusahaan. Manajer harus mengadakan pengawasan terhadap modal kerja, agar sumbersumber modal kerja dapat digunakan secara efektif dan efisien. Efektif dan efisiennya modal kerja merupakan ketepatan strategi dalam menjalankan sesuatu, serta tidak membuang waktu, tenaga, biaya dengan mengupayakan agar modal kerja yang tersedia tidak kelebihan (idle) dan tidak juga kekurangan (Brigham \& Houston, 2011). Keefektifan modal kerja dapat diketahui dengan seberapa banyak perputaran kas, perputaran persediaan, serta perputaran piutangnya mengalami perputaran. Sedangkan efisiennya modal kerja dapat diketahui dari seberapa banyak perputaran modal kerjanya, dan laba operasi yang didapat.

Perputaran kas merupakan periode berputarnya kas yang dimulai pada saat kas diinvestasikan dalam komponen modal kerja sampai kembali menjadi kas. Dimana semakin tinggi perputaran kas perusahaan menandakan semakin baik kas yang dimiliki. Hal ini menjelaskan semakin tinggi efisiensi pengelolaan kasnya dan keuntungan yang didapat, begitupun sebaliknya. Adapun fungsi perputaran kas yaitu untuk mengukur kecukupan modal kerja dalam membayar kewajiban dan membiayai penjualan. Sedangkan perputaran piutang adalah gambaran waktu yang dibutuhkan untuk mengubah piutang menjadi kas, dari setiap penjualan yang dilakukan secara kredit oleh perusahaan. Terlalu lama waktu yang dibutuhkan untuk mengubah piutang menjadi kas, ini menjelaskan bahwa kebijakan penjualan secara kredit terlalu liberal atau bebas, dan akan menimbulkan piutang bermasalah ( $\mathrm{bad}$ debt) yaitu investasi dalam piutang menjadi terlalu besar yang mengakibatkan keuntungan perusahaan menurun (Sartono, 2016). Dalam menilai keefektifan modal kerja perusahaan selain perputaran kas, dan perputaran piutang, tentunya harus diperhatikan juga perputaran persediaan. Perputaran persediaan sendiri menjelaskan seberapa optimal persediaan yang dimiliki berputar dalam satu periode. Banyaknya persediaan yang ada diperusahaan akan mengakibatkan perputaran persediaan lambat, sehingga akan memperbesar beban persediaan sehingga akan mempengaruhi laba yang didapat perusahaan. Apabila persediaan yang dimiliki oleh perusahaan sedikit tentunya akan menyebabkan hilangnya kesempatan untuk mendapatkan keuntungan, dan hilangnya kepercayaan dari konsumen. Sedangkan efisiensi modal kerja dapat dilihat dari seberapa banyak modal kerja perusahaan dapat berputar, berputarnya modal kerja secara maksimal tentunya akan menghasilkan keuntungan terutama pada tingkat keuntungan dari pemanfaatan aset perusahaan. Efektivitas dan efisiensi dari modal kerja akan mempengaruhi 
perusahaan dalam memperoleh laba, terutama pada perolehan laba dari aktivitas aset lancar.

Return on assets merupakan kemampuan perusahaan dalam menghasilkan laba bersih atas penggunaan seluruh sumber daya atau aset yang dimiliki (Hanafi, 2016). Return on assets dapat menunjukkan efisiensi dan efektivitas pengelolaan aset perusahaan. Dimana semakin besar laba bersih yang dihasilkan dari aktivitas seluruh aset, maka persentase keuntungan yang diterima akan semakin besar dan menunjukkan aset perusahaan dapat bekerja dengan maksimal. Sedangkan jika laba bersih yang dihasilkan kecil, memiliki arti bahwa aset bekerja tidak maksimal.

Perusahaan semen yang terdaftar pada Bursa Efek Indonesia yaitu PT Indocement Tunggal Prakarsa Tbk, PT Semen Indonesia Tbk, dan PT Wijaya Karya Beton Tbk, mengalami permasalahan dalam efektivitas dan efisiensi modal kerjanya, yang menyebabkan perolehan laba dari aktivitas aset cenderung mengalami penurunan. Dapat dilihat pada tabel di bawah ini:

Tabel 1 Efektivitas dan Efisiensi Modal Kerja

\begin{tabular}{|c|c|c|c|c|c|c|}
\hline \multirow{3}{*}{$\begin{array}{c}\text { NAMA } \\
\text { PERUSAHAAN }\end{array}$} & \multirow{3}{*}{ TAHUN } & \multicolumn{3}{|c|}{ EFEKTIFITAS } & \multirow{3}{*}{$\begin{array}{c}\text { PERPUTARAN } \\
\text { MODAL KERJA } \\
\% \\
\end{array}$} & \multirow{3}{*}{$\begin{array}{c}\text { RETURN ON } \\
\text { ASSET } \\
\% \\
\end{array}$} \\
\hline & & PERPUTARAN & PERPUTARAN & PERPUTARAN & & \\
\hline & & & & & & \\
\hline \multirow{4}{*}{$\begin{array}{c}\text { PT } \\
\text { INDOCEMENT } \\
\text { TUNGGAL } \\
\text { PRAKARSA Tbk } \\
\end{array}$} & 2016 & 159 & 587 & 507 & 106 & 13 \\
\hline & 2017 & 174 & 576 & 533 & 112 & 6 \\
\hline & 2018 & 210 & 508 & 589 & 123 & 4 \\
\hline & 2019 & 208 & 528 & 551 & 124 & 7 \\
\hline PT SEMEN & 2016 & 922 & 650 & 609 & 252 & 10 \\
\hline \multirow{3}{*}{ INDONESIA } & 2017 & 765 & 557 & 539 & 202 & 4 \\
\hline & 2018 & 585 & 515 & 603 & 191 & 2 \\
\hline & 2019 & 1022 & 588 & 596 & 242 & 2 \\
\hline PT WIJAYA & 2016 & 1378 & 500 & 429 & 42 & 4.6 \\
\hline \multirow{2}{*}{ KARYA BETON } & 2017 & 1114 & 332 & 454 & 61 & 6.7 \\
\hline & 2018 & 925 & 257 & 501 & 78 & 7.2 \\
\hline Tbk & 2019 & 466 & 207 & 534 & 77 & 5 \\
\hline \multicolumn{2}{|l|}{ Rat } & 660,67 & 483,75 & 537,08 & 134,17 & 5,89 \\
\hline
\end{tabular}

Sumber: Data diolah

Berdasarkan tabel di atas dapat dijelaskan bahwa dari rata-rata industri perputaran kas sebesar 660,67\%, perputaran piutang $483,75 \%$, perputaran persediaan 537,08\%. Hal ini menandakan bahwa dari ketiga perusahaan tersebut yang memiliki perputaran kas di atas rata-rata industri adalah PT Semen Indonesia, dan PT Wijaya Karya Beton. Untuk perputaran kas Semen Indonesia pada tahun 2018, dan Wijaya Karya Beton pada tahun 2019 tidak mencapai rata-rata industri yang sudah ditentukan. Sedangkan untuk perputaran piutang yang berada di atas rata-rata industri adalah PT Indocement Tunggal Prakarsa dan PT Semen Indonesia. Sedangkan untuk perputaran persediaannya yang dilakukan oleh ketiga perusahaan tersebut, hanya PT Semen Indonesi, begitupun untuk PT Indocement Tunggal Prakarasa perputaran persediaan yang di atas standar industri yaitu di tahun 2018 dan 2019. Tetapi perputaran persediaan dari ketiga perusahaan memiliki tren meningkat. Selain itu perputaran persediaan yang dilakukan masih berada di bawah rata-rata industrinya. Untuk perputaran modal kerja dari ketiga 
perusahaan tersebut memiliki standar industri $134,17 \%$. Perputaran modal kerja yang kurang baik, dilakukan oleh PT Wijaya Karya Beton. Di mana perputarannya tidak mencapai $100 \%$ atau satu kali putaran, dan perputaran modal kerja yang optimal dilakukan oleh PT Semen Indonesia yang memiliki perputaran mencapai $200 \%$ atau 2 kali putaran. Adapun untuk PT Indocement Tunggal Prakarsa perputaran modal kerjanya, mengalami tren menanjak. Return on asset dari ketiga perusahaan tersebut standar industrinya $5,89 \%$. Perusahaan yang dapat meningkatkan perolehan return on assetnya, adalah PT Indocement Tunggal Prakarsa dan Wijaya Karya Beton, sedangkan untuk PT Semen Indonesia return on asset yang didapat selalu mengalami penurunan dan belum dapat mingkatkannya kembali. Efektivitas dan efisiensi modal kerja

\section{KAJIAN PUSTAKA DAN PENGEMBANGAN HIPOTESIS}

Dalam operasional keseharian perusahaan, modal kerja memiliki peran utama untuk menjaga kelangsungan hidup perusahaan terjamin, tentunya modal kerja harus digunakan secara efektiv dan efisien. Efektivnya modal kerja dapat dilihat dari perputaran kas, perputaran piutang dan juga perputaran persediaan yang tingkat perputarannya tidak lebih dari satu tahun. Sedangkan efisiennya modal kerja terlihat dari banyaknya perputaran yang dilakukan.

\section{Pengertian Perputaran Kas}

Kas merupakan aset lancar yang paling penting, dikarenakan kas merupakan salah satu jaminan perusahaan dalam menanggulangi kewajiban-kewajiban jangka pendek yang akan jatuh tempo. Untuk mengetahui apakah kas yang dimiliki perusahaan baik atau tidak, dapat dilakukan dengan menghitung berapa kali kas perusahaan mengalami perputaran. Semakin besar perputaran yang dilakukan menandakan semakin yang baik, belum tentu dapat menghasilkan return on asset yang baik. Efektivitas modal kerja (perputaran kas, perputaran piutang, perputaran persedian) dan efisiensi modal kerja (perputaran modal kerja) tentunya akan mempengaruhi perolehan keuntungan atas asetnya (ROA), hal ini sejalan dengan penelitian yang dilakukan oleh L. Rajagukguk, S. Dini, S. Silalahi, E. Marpaung, (2020) yang menyatakan bahwa adanya pengaruh positif dan signifikanantara efektivitas dan efisiensi penggunaan modal kerja terhadap profitabilitas (ROA).

Dari uraian di atas penulis tertarik untuk melakukan penelitian dengan mengambil judul efektivitas dan efisiensi penggunaan modal kerja dalam mempengaruhi perolehan return on asset pada perusahaan semen yang terdaftar di Bursa Efek Indonesia (BEI).

sedikit kas yang dimiliki dan menunjukkan efisiennya penggunaan kas, dan semakin kecil perputaran kas menandakan kas yang dimiliki besar sehingga mengakibatkan banyaknya uang kas yang tidak produktif dan tentunya akan berkurangnya profitabilitas perusahaan. "Perputaran kas adalah banyaknya uang yang ada dikas perusahaan mengalami perputaran dalam satu periode melalui penjualan" (Nurafika, 2018). Perputaran kas dapat diketahui dengan cara membandingkan antara penjualan dan rata-rata kas perusahaan.

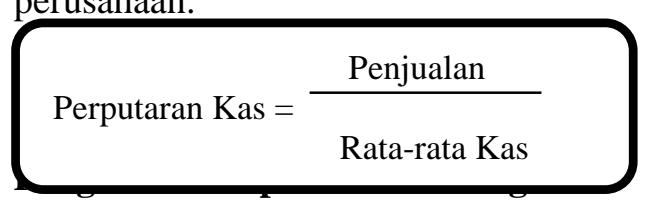

Piutang merupakan penjualan yang dilakukan secara kredit, di mana perusahaan tidak mendapatkan pembayaran secara langsung disaat barang diterima oleh pelanggan. Akan tetapi pembayaran akan diterima berdasarkan jangka waktu yang diberikan perusahaan kepada pelanggan. 
Dengan dilakukannya penjualan secara kredit ini, tentunya akan berpengaruh kepada keuntungan yang didapat. Jika penjualan dilakukan secara tunai, maka akan mendapatkan keuntung secara langsung, sedangkan penjualan yang dilakukan secara kredit keuntungan akan diperoleh pada saat pembayaran dilakukan oleh pelanggan.

Perputaran piutang merupakan salah satu langkah untuk mengetahui besaran penjualan yang dilakukan secara kredit dan waktu yang dibutuhkan oleh perusahaan untuk mengkonversi piutang menjadi kas. Semakin tinggi perputaran piutang, ini menunjukkan bahwa modal kerja yang ditanamkan dalam piutang semakin rendah. Begitupun sebaliknya jika perputaran piutang rendah, menunjukkan modal kerja yang ditanamkan dalam piutang semakin besar (Kasmir, 2017). Kualitas piutang dipengaruhi oleh tingkat perputarannya, kualitas merujuk kepada kemungkinan tertagihnya piutang melebihi tanggal jatuh temponya. Tentunya akan mempengaruhi pada perolehan keuntungan, terutama perolehan return on assetnya. Perputaran piutang dapat diketahui dengan cara membandingkan penjualan yang dilakukan secara kredit dengan rata-rata piutang yang diberikan oleh perusahaan.

$$
\text { Perputaran Piutang }=\frac{\text { Penjualan Kredit }}{\text { Rata-rata Piutang }}
$$

Persediaan merupakan bahan

baku, barang dalam proses, barang setengah jadi, dan barang jadi yang dimiliki perusahaan yang siap dijual (Keown et al., 2010). Perputaran persediaan merupakan salah satu cara untuk mengukur jangka waktu yang dibutuhkan oleh perusahaan untuk mengubah persediaan menjadi kas melalui penjualan. Semakin cepat waktu yang diperlukan perusahaan untuk menjual persediaan, tentunya akan mempengaruhi laba yang dihasilkan dan berdampak pada return on assets. Perputaran persediaan wajib dilakukan setiap perusahaan, pengelolaan persediaan yang baik akan mendukung kelancaran penjualan. Perputaran persediaan yang tinggi menunjukkan efektivnya perusahaan dalam mengelola persediaannya, sedangkan perputaran persediaan yang rendah menandakan perusahaan tidak mampu mengelola persediaannya dengan efektiv (Hanafi, 2016). Adapun untuk mengetahui perputaran persediaan yaitu dengan membandingkan antara harga pokok penjualan dan rata-rata persediaan

\section{Pengertian Perputaran Modal Kerja}

Tingkat efisiensi penggunaan modal kerja menjadi sangat penting untuk pertumbuhan dan kelangsungan perusahaan dalam jangka panjang. Apabila perusahaan kekurangan modal kerja untuk meningkatkan penjualan, maka besar kemungkinan akan kehilangan pendapatan dan keuntungan. Perputaran modal kerja merupakan tolak ukur dalam memperoleh profitabilitas. Apabila perputaran modal kerja rendah , dapat diartikan perusahaan sedang kelebihan modal kerja. Dan apabila perputaran modal kerja tinggi, menandakan modal kerja yang dimiliki perusahaan optimal. Fasilitas permodalan yang memadai merupakan faktor utama dalam aktivitas kegiatan perusahaan, yang akan memberikan dampak bagi perkembangan perusahaan di masa yang akan datang. Perputaran modal kerja atau working capital turn over merupakan hubungan antara modal kerja dengan penjualan dan menunjukkan banyaknya penjualan yang dapat menghasilkan keuntungan perusahaan dari tiap rupiah modal kerja (Munawir, 2004). Untuk mengetahui perputaran modal kerja dapat dilakukan dengan membandingkan antara penjualan dengan modal kerja.

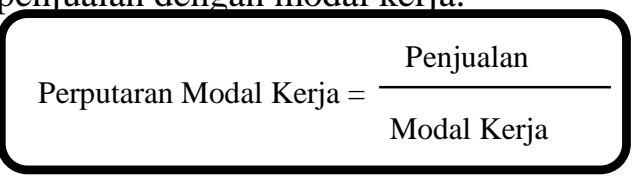




\section{Pengertian Return On Asset}

Tujuan akhir yang ingin dicapai oleh suatu perusahaan adalah memperoleh laba atau keuntungan yang maksimal. Profitabilitas merupakan hasil akhir bersih dari berbagai kebijaksanaan dan keputusan manajemen, yang merupakan jawaban akhir tentang seberapa efektif dan efisiennya

Perputaran Persediaan $=\frac{\text { HPP }}{\text { Rata-rata }}$

return on assets (ROA) yang mencerminkan seberapa besar pengembalian yang dihasilkan atas setiap rupiah uang yang ditanamkan dalam bentuk aset (Brigham \& Houston, 2011). Return on asset rendah menunjukkan bahwa aset yang digunakan tidak maksimal, sehingga laba yang dihasilkan rendah. Rendahnya laba diakibatkan dari penggunaan hutang dalam jumlah besar,

Dari uraian di atas, dapat diambil kerangka pemikiran sebagai berikut: sehingga beban bunga tinggi dan membuat rendahnya return on asset. Sedangkan return on asset tinggi menunjukkan bahwa aset yang digunakan maksimal. Untuk mengetahui return on asset perusahaan, dapat membandingkan antara laba bersih dengan total aset yang dimiliki perusahaan.

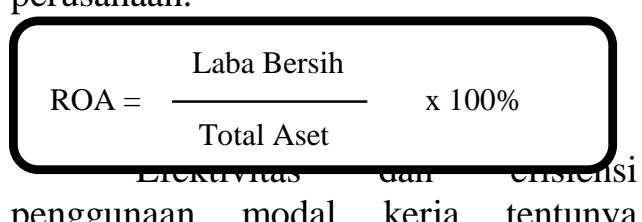
memiliki pengaruh dalam memperoleh profitabilitas, terutama return on asset. Dari penelitian yang dilakukan oleh (Suryanto, 2020), menyatakan bahwa efektivitas modal kerja (perputaran kas, perputaran piutang, perputaran persediaan), dan efisiensi modal kerja (perputaran modal kerja) mempengaruhi return on asset.

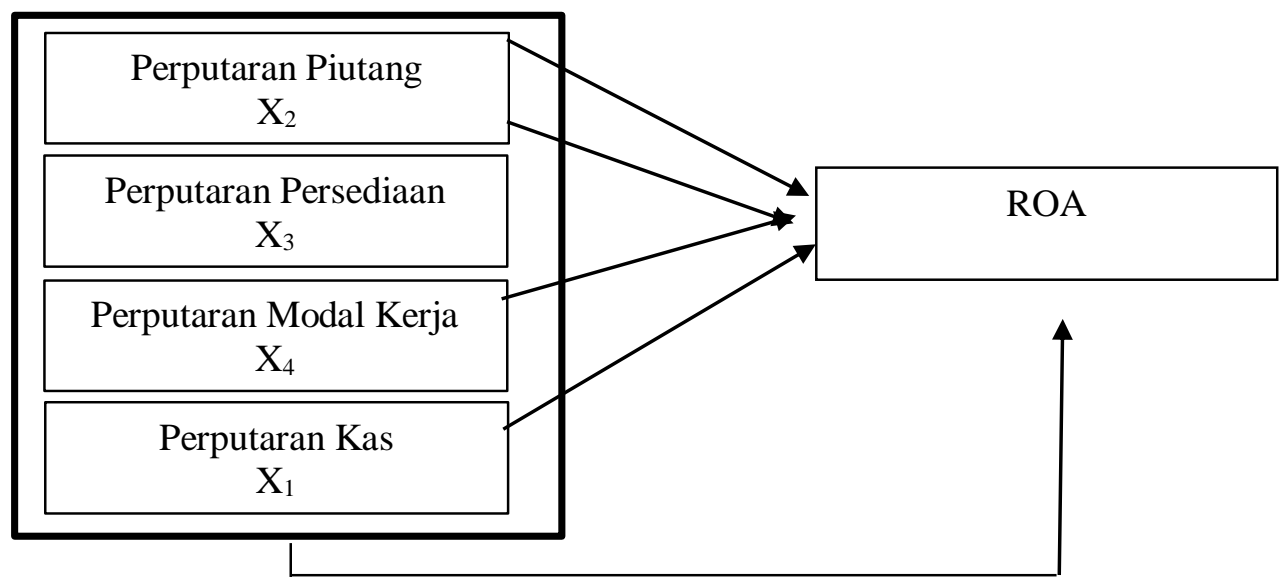

\section{Hipotesis Penelitian}

Berdasarkan kajian teori dan kerangka berfikir, hipotesis pada penelitian ini dapat sebagai berikut:

1. Perputaran kas memiliki pengaruh signifikan terhadap perolehan return on asset

2. Perputaran piutang memiliki pengaruh signifikan terhadap perolehan return on asset

3. Perputaran persediaan memiliki pengaruh signifikan terhadap perolehan return on asset

4. Perputaran modal kerja memiliki pengaruh signifikan terhadap perolehan return on asset 
5. Perputaran kas, perputaran piutang, perputaran persediaan, dan perputaran modal kerja memiliki pengaruh signifikan terhadap perolehan return on asset.

\section{METODE PENELITIAN Objek Penelitian}

Objek penelitian merupakan permasalahan yang diteliti. Adapun objek dari penelitian ini adalah Perputaran Kas $\left(\mathrm{X}_{1}\right)$, Perputaran Perputaran Piutang $\left(\mathrm{X}_{2}\right)$, Perputaran Persediaan $\left(\mathrm{X}_{3}\right)$, Perputaran Modal Kerja $\left(\mathrm{X}_{4}\right)$ dan Return on Asset (Y). penelitian ini dilaksanakan pada perusahaan Semen yang terdaftar pada Bursa Efek Indonesia yaitu PT Indocement Tunggal Prakarsa, PT Semen Indonesia, dan PT Wijaya Karya Beton. Data yang digunakan adalah laporan keuangan dari tahun 2016 sampai dengan tahun 2019, yang diperoleh dari web: (Www.Idx.Co.Id, n.d.).

\section{Metode Penelitian}

Metode penelitian yang digunakan adalah untuk menjawab rumusan masalah dan menguji hipotesis penelitian yang diajukan. Dalam penelitian ini, penulis menggunakan metode eksplanatif analisis dengan pendekatan kuantitatif, yaitu metode penelitian yang digunakan untuk menemukan penjelasan fenomena yang dihadapi, masalah, atau perilaku. Penelitian eksplanatory adalah suatu metode penelitian yang bermaksud menjelaskan kedudukan variabelvariabel yang diteliti serta hubungan kausal antara variabel satu dengan yang lain melalui pengujian hipotesis (Sugiyono, 2014). Pendekatan kuantitatif yaitu memfokuskan permasalahan pada variabel (konsep yang memiliki nilai) dan dicari hubungan antara variabel tersebut dengan menggunakan teori yang sudah ada. Pendekatan kuantitatif mengukur variabel dalam bentuk angkaangka dengan menggunakan analisis statistik (Sugiyono, 2018).

\section{HASIL PENELITIAN DAN} PEMBAHASAN

Analisis Regresi Linear Berganda

Analisis regresi linier berganda bertujuan untuk mengetahui arah hubungan antara variabel independent dengan variabel dependent apakah masing-masing dari variabel independent berhubungan positif atau negative dan untuk memprediksi nilai dari variabel dependent, apabila variabel independent mengalami kenaikan atau penurunan (Priyatno, 2012). Dengan persamaan regresi linier berganda adalah: $\mathbf{Y}=\mathbf{a}+$ $b_{1} X_{1}+b_{2} X_{2}+b_{3} X_{3}+b_{4} X_{4}+e$.

Tabel 2 Analisis Regresi Linear Berganda

\begin{tabular}{|c|c|c|c|c|c|c|}
\hline \multicolumn{7}{|c|}{ Coefficients $^{\mathrm{a}}$} \\
\hline & \multirow[t]{2}{*}{ Model } & \multicolumn{2}{|c|}{$\begin{array}{l}\text { Unstandardized } \\
\text { Coefficients }\end{array}$} & \multirow{2}{*}{$\begin{array}{c}\begin{array}{c}\text { Standardized } \\
\text { Coefficients }\end{array} \\
\text { Beta }\end{array}$} & \multirow[b]{2}{*}{$\mathrm{t}$} & \multirow[b]{2}{*}{ Sig. } \\
\hline & & $\mathrm{B}$ & Std. Error & & & \\
\hline \multirow[t]{5}{*}{1} & (Constant) & 35.126 & 27.267 & & 1.288 & .239 \\
\hline & Perputaran_Kas & -.005 & .004 & -.635 & -1.204 & .268 \\
\hline & Perputaran_Piutang & .001 & .011 & .040 & .078 & .940 \\
\hline & Perputaran_Persediaan & -.057 & .051 & -1.029 & -1.099 & .308 \\
\hline & Perputaran_Modal_Kerja & .029 & .047 & .654 & .628 & .550 \\
\hline
\end{tabular}

Berdasarkan hasil perhitungan SPSS sebagaimana tabel di atas bahwa persamaan regresi berganda adalah sebagai berikut : 
$\mathrm{Y}=35,126-0,005$ Perputaran Kas + 0,001 Perputaran Piutang - 0,057

Perputaran Persediaan $+0,029$

Perputaran Modal Kerja + e

Dari hasil regresi tersebut maka dapat dijelaskan bahwa :

1. Nilai konstanta sebesar 35,126 artinya jika perputaran kas, perputaran piutang, perputaran persediaan, dan perputaran modal kerja nilainya 0 , maka return on asset nilainya sebesar 35,126.

2. Nilai koefisien regresi perputaran kas adalah -0,005 dan bertanda negative, yang artinya apabila perputaran kas meningkat satu satuan maka akan mengurangi return on asset sebesar 0,005 .

3. Nilai koefisien regresi perputaran piutang adalah sebesar 0,001 dan bertanda positif yang artinya apabila perputaran piutang mengalami kenaikan satu satuan, maka akan meningkatkan return on asset sebesar 0,001 .

4. Nilai koefisien regresi perputaran persediaan adalah $-0,057$ dan bertanda negative, yang memiliki arti jika perputaran perputaran persediaan meningkat satu satuan maka akan mengurangi return on asset sebesar -0,057.

5. Nilai koefisien regresi perputaran modal kerja adalah sebesar 0,029 dan bertanda positif yang artinya apabila perputaran modal kerja mengalami kenaikan satu satuan, maka akan meningkatkan return on asset sebesar 0,029.

\section{Analisis Koefisien Determinasi}

Uji koefisien determinasi $\left(\mathrm{R}^{2}\right)$ bertujuan untuk mengukur sejauh mana variabel bebas dapat menjelaskan variasi variabel terikat, baik secara parsial maupun simultan. Berikut ini hasil perhitungan analisis koefisien determinasi:

Tabel 3 Hasil Analisis Keofisien Determinasi

\begin{tabular}{|c|c|c|c|c|}
\hline \multicolumn{5}{|c|}{ Model Summary } \\
\hline Model & $\mathrm{R}$ & R Square & Adjusted R Square & $\begin{array}{l}\text { Std. Error of } \\
\text { the Estimate }\end{array}$ \\
\hline 1 & $.527^{\mathrm{a}}$ & .278 & -.135 & 3.38273 \\
\hline
\end{tabular}

a. Predictors: (Constant), Perputaran_Modal_Kerja, Perputaran_Kas, Perputaran_Piutang, Perputaran_Persediaan

Berdasarkan tabel di atas dapat dijelaskan bahwa nilai koefisien determinasi sebesar 0,278 atau $27,8 \%$ yang artinya variasi perubahan return on asset (ROA) dipengaruhi oleh perputaran kas, perputaran piutang, perputaran persediaan, dan perputaran modal kerja sebesar $27,8 \%$ sedangkan sisanya $72,2 \%$ dipengaruhi oleh faktor lain diluar yang penulis teliti.

\section{Uji t (Parsial)}

Uji $t$ digunakan untuk menguji signifikansi pengaruh perputaran kas, perputaran piutang, perputaran persediaan dan perputaran modal kerja secara parsial, yaitu untuk menguji bagaimana pengaruh masing-masing variabel bebas secara sendiri-sendiri terhadap variabel terikatnya. Uji $t$ dapat dilakukan dengan membandingkan antara $t_{\text {hitung }}$ dengan $t_{\text {tabel }}$ atau dengan melihat kolom signifikansi pada masingmasing $t_{\text {hitung. Kriteria pengujian taraf uji }}$ signifikan $(\alpha)=5 \%: 2=2,25 \%(0,025)$ dan diuji dua sisi, dengan derajat kebebasan (df) n-2 atau 12-4-1 = 7, maka nilai dari $t_{\text {tabel }}$ adalah sebesar 2,365. Dan dapat dilihat hasil dari $t_{\text {hitung }}$ sebagai berikut: 
Tabel 4 Uji t

\begin{tabular}{|c|c|c|c|c|c|c|}
\hline \multicolumn{7}{|c|}{ Coefficients $^{\mathrm{a}}$} \\
\hline & \multirow{2}{*}{ Model } & \multicolumn{2}{|c|}{$\begin{array}{c}\text { Unstandardized } \\
\text { Coefficients }\end{array}$} & \multirow{2}{*}{$\begin{array}{c}\begin{array}{c}\text { Standardized } \\
\text { Coefficients }\end{array} \\
\text { Beta } \\
\end{array}$} & \multirow[b]{2}{*}{$\mathrm{t}$} & \multirow[b]{2}{*}{ Sig. } \\
\hline & & $\mathrm{B}$ & Std. Error & & & \\
\hline \multirow[t]{5}{*}{1} & (Constant) & 35.126 & 27.267 & & 1.288 & .239 \\
\hline & Perputaran_Kas & -.005 & .004 & -.635 & -1.204 & .268 \\
\hline & Perputaran_Piutang & .001 & .011 & .040 & .078 & .940 \\
\hline & Perputaran_Persediaan & -.057 & .051 & -1.029 & -1.099 & .308 \\
\hline & Perputaran Modal Kerja & .029 & .047 & .654 & .628 & .550 \\
\hline
\end{tabular}

1. Pengujian hipotesis perputaran kas $\left(\mathrm{X}_{1}\right)$ terhadap Return on Asset $(\mathrm{Y})$ dari hasil perhitungan $\mathrm{t}_{\text {hitung }}(-1,204)<\mathrm{t}_{\text {tabel }}$ $(2,365)$ dan sig $t(0,268)>0,05$ dengan demikian $\mathrm{H}_{0}=$ diterima dan $\mathrm{H}_{1}=$ ditolak. Maka dapat diartikan bahwa pada taraf uji signifikan 0,05 tidak terdapat pengaruh yang signifikan antara perputaran kas terhadap return on asset (ROA).

2. Pengujian hipotesis perputaran piutang $\left(\mathrm{X}_{2}\right)$ terhadap Return on Asset (Y) dari hasil perhitungan $t_{\text {hitung }}$ $(0,078)<\mathrm{t}_{\text {tabel }}(2,365)$, atau sig $\mathrm{t}$ $(0,940)>0,05$, dengan demikian $\mathrm{H}_{0}=$ diterima $\mathrm{H}_{1}=$ ditolak. Maka dapat diartikan pada taraf uji signifikan 0,05 , tidak terdapat pengaruh yang signifikan antara perputaran piutang terhadap return on asset (ROA).

3. Pengujian hipotesis perputaran persediaan $\left(\mathrm{X}_{3}\right)$ terhadap Return on Asset (Y) dari hasil perhitungan $t_{\text {hitung }}$ $(-1,099)<t_{\text {tabel }}(2,365)$, atau sig $\mathrm{t}$ $(0,308)>0,05$, dengan demikian $\mathrm{H}_{0}=$ diterima $\mathrm{H}_{1}=$ ditolak. Maka dapat diartikan pada taraf uji signifikan 0,05 , tidak terdapat pengaruh yang signifikan antara perputaran persediaan terhadap return on asset (ROA).

4. Pengujian hipotesis perputaran modal kerja $\left(\mathrm{X}_{4}\right)$ terhadap Return on Asset (Y) dari hasil perhitungan $t_{\text {hitung }}$ $(0,628)<\mathrm{t}_{\text {tabel }}(2,365)$, atau sig $\mathrm{t}$ $(0,550)>0,05$, dengan demikian $\mathrm{H}_{0}=$ diterima $\mathrm{H}_{1}=$ ditolak. Maka dapat diartikan pada taraf uji signifikan 0,05 , tidak terdapat pengaruh yang signifikan antara perputaran modal kerja terhadap return on asset (ROA).

\section{Uji F (Simultan)}

Uji F digunakan untuk menguji signifikansi perputaran kas, perputaran piutang, perputaran persediaan, perputaran modal kerja secara bersamasama terhadap return on asset (ROA) atau secara simultan. Kriteria pengujian taraf uji signifikan $=0,05$ dengan $\mathrm{df}=\mathrm{n}$ $\mathrm{k}$ maka nilai $\mathrm{F}_{\text {tabel }}=4,120$. Dan nilai $\mathrm{F}_{\text {hitung }}$ sebagai berikut:

Tabel 8 Uji F

\begin{tabular}{|c|c|c|c|c|c|c|}
\hline \multicolumn{7}{|c|}{ ANOVA $^{a}$} \\
\hline \multicolumn{2}{|c|}{ Model } & $\begin{array}{l}\text { Sum of } \\
\text { Squares }\end{array}$ & $\mathrm{df}$ & $\begin{array}{l}\text { Mean } \\
\text { Square }\end{array}$ & $\mathrm{F}$ & Sig. \\
\hline \multirow[t]{3}{*}{1} & Regression & 30.769 & 4 & 7.692 & .672 & $.632^{\mathrm{b}}$ \\
\hline & Residual & 80.100 & 7 & 11.443 & & \\
\hline & Total & 110.869 & 11 & & & \\
\hline
\end{tabular}

a. Dependent Variable: ROA

b. Predictors: (Constant), Perputaran_Modal_Kerja, Perputaran_Kas,

Perputaran_Piutang, Perputaran_Persediaan 
Dari hasil perhitungan di atas menunjukkan bahwa $F_{\text {hitung }}(0,672)<$ $\mathrm{F}_{\text {tabel }}(4,120)$ dan signifikansinya $0,632>$ 0,05 maka dengan demikian $\mathrm{H}_{0}=$ diterima dan $\mathrm{H}_{1}=$ ditolak. Dapat disimpulkan pada taraf uji signifikansi 0,05 tidak terdapat pengaruh yang signifikan antara perputaran kas, perputaran piutang, perputaran persediaan, perputaran modal kerja terhadap return on aAsset.

\section{Pengaruh Perputaran Kas terhadap Return on Asset}

Berdasarkan hasil pengujian secara parsial di atas menunjukkan bahwa tidak terdapat pengaruh yang signifikan antara perputaran kas terhadap return on asset (ROA), hal ini ditunjukkan oleh signifikansinya yaitu $0,268>0,05$, (di atas 0,05). Di mana pengaruh perputaran kas terhadap ROA hanya $5,8 \%$. Perputaran kas yang tinggi akan meningkatkan perolehan profitabilitas terutama ROA, begitupun sebaliknya. Hasil penelitian ini sejalan dengan penelitian yang dilakukan oleh (Canizio, 2017), yang menyatakan bahwa terjadi pengaruh yang tidak signifikan antara perputaran kas terhadap profitabilitas (ROA). Perputaran kas yang dilakukan oleh ketiga perusahaan semen tersebut pada dasar belum maksimal, sehingga tidak maksimal dalam memperoleh keuntungan terutama ROA.

\section{Pengaruh Perputaran Piutang terhadap Return on Asset}

Berdasarkan hasil pengujian secara parsial di atas menunjukkan bahwa tidak terdapat pengaruh yang signifikan antara perputaran piutang terhadap return on asset (ROA), hal ini ditunjukan oleh signifikansinya yang berada di atas alpha (@) yaitu 0,05. Sehingga dapat dinyatakan sig t perputaran piutang $0,940>0,05$ dan pengaruh perputaran piutang terhadap ROA hanya $1,3 \%$. Dimana piutang yang tinggi akan menyebabkan waktu yang dibutuhkan untuk mengubah piutang menjadi kas akan lebih lama, sehingga perputarannya yang dihasilkan rendah dan akan berpengaruh pada rendahnya perolehan profitabilitas terutama return on asset. Begitupun jika piutang rendah, waktu yang dibutuhkan untuk mengubah piutang menjadi kas lebih cepat dan akan menyebabkan perputaran piutang tinggi. Tentunya akan berpengaruh pada optimalnya perolehan return on asset.

\section{Pengaruh Perputaran Persediaan terhadap Return on Asset}

Dari hasil pengujian secara parsial di atas menunjukkan bahwa tidak terdapat pengaruh yang signifikan antara perputaran persediaan terhadap return on asset (ROA), dimana signifikansinya 0,308 berada di atas alpha (@) yaitu 0,05. Adapun pengaruh perputaran persediaan terhadap ROA sebesar 5,3\%. Dimana persediaan yang banyak akan menyebabkan terhambatnya penjualan, dan akan membutuhkan waktu yang lama untuk mengubahnya menjadi kas. Sehingga akan mempengaruhi perputaran yang dilakukan, perputaran yang tinggi menandakan persediaan yang ada optimal dan perputaran persediaan yang rendah menandakan persediaan melimpah tentunya akan mempengaruhi perolehan return on asset.

\section{Pengaruh Perputaran Modal Kerja terhadap Return on Asset}

Dari hasil pengujian secara parsial menunjukkan bahwa tidak terdapat pengaruh yang signifikan antara perputaran modal kerja terhadap return on asset (ROA), di mana signifikansinya 0,550 berada di atas alpha (@) yaitu 0,05 dan pengaruhnya sebesar $3,2 \%$. Jika modal kerja berputar dengan optimal maka profitabilitas (ROA) yang didapat akan mengalami peningkatan dan apabila modal kerja berputar lamban maka pencapaian profitabilitas (ROA) tidak akan maksimal. Akan tetapi adapula perputaran modal kerja yang tinggi 
belum tentu menghasilkan profit, dan adapula perputaran modal kerja yang kurang maksimal dapat menghasilkan profit. Pada umumnya perputaran modal kerja yang tinggi dapat menghasilkan profit yang besar dan perputaran modal kerja yang rendah akan mendapatkan profit yang rendah.

\section{Pengaruh Perputaran Kas, Perputaran Piutang, Perputaran Persediaan, dan Perputaran Modal Kerja terhadap Return on Asset Berdasarkan dari hasil uji simultan menunjukkan bahwa tidak terdapat pengaruh yang
signifikan antara perputaran kas, 5. KESIMPULAN \\ Berdasarkan hasil penelitian tentang efektivitas modal kerja (perputaran kas, perputaran piutang, perputaran persediaan) dan efisiensi modal kerja (perputaran moal kerja) terhadap return on asset, maka dapat ditarik kesimpulan sebagai berikut:}

a. Perputaran kas tidak berpengaruh signifikan terhadap return on asset, berdasarkan pengujian secara parsial nilai signifikansi dari perputaran kas terhadap ROA di atas 0,05 yaitu 0,268 yang menerangkan bahwa $\mathrm{H}_{0}$ diterima dan $\mathrm{H}_{1}$ ditolak. Artinya perputaran kas yang dilakukan oleh perusahaan tidak maksimal, di mana pengaruh dari perputaran kas terhadap ROA hanya 5,8\%.

b. Perputaran piutang tidak berpengaruh signifikan terhadap return on asset, dari hasil uji t atau secara parsial nilai dari perputaran piutang terhadap ROA berada di atas 0,05 yaitu 0,940 yang menunjukkan bahwa $\mathrm{H}_{0}$ diterima dan $\mathrm{H}_{1}$ ditolak. Artinya bahwa perputaran piutang yang dilakukan oleh perusahaan belum maksimal, dan pengaruh dari perputaran piutang terhadap ROA hanya $1,3 \%$. Hal ini memiliki makna perputaran piutang, perputaran persediaan, perputaran modal kerja terhadap return on asset. Hal ini ditunjukan oleh nilai $F_{\text {hitung }}(0,672)<F_{\text {tabel }}$ $(3,84)$ dan nilai signifikansinya yaitu 0,632 yang berada di atas 0,05 , artinya $\mathrm{H}_{0}$ $=$ diterima $\mathrm{H}_{1}=$ ditolak. Dimana pengaruh dari perputaran kas, perputaran piutang, perputaran persediaan, dan perputaran modal kerja terhadap ROA hanya $27,8 \%$, ini menandakan kurang efektif dan efisien modal kerja yang digunakan oleh perusahaan, sehingga profitabilitas yan didapat tidak maksimal terutama return on asset.

bahwa perputaran piutang sangat rendah dalam mempengaruhi ROA.

c. Perputaran persediaan tidak berpengaruh signifikan terhadap return on asset, hasil uji t atau secara parsial nilai dari perputaran persediaan terhadap ROA berada di atas 0,05 yaitu 0,308 yang menunjukkan bahwa $\mathrm{H}_{0}$ diterima dan $\mathrm{H}_{1}$ ditolak. Artinya bahwa perputaran persediaan yang dilakukan oleh perusahaan tidak maksimal, dan pengaruh dari perputaran persediaan terhadap ROA hanya 5,3\%. Hal ini memiliki makna bahwa perputaran persediaan rendah menandakan persediaan yang ada banyak, sehingga rendah dalam mempengaruhi ROA.

d. Perputaran modal kerja tidak berpengaruh signifikan terhadap return on asset, dari hasil uji $\mathrm{t}$ atau secara parsial nilai perputaran modal kerja terhadap ROA berada di atas 0,05 yaitu 0,550 yang menunjukkan bahwa $\mathrm{H}_{0}$ diterima dan $\mathrm{H}_{1}$ ditolak. Artinya bahwa perputaran modal kerja perusahaan tidak maksimal, dimana pengaruh dari perputaran modal kerja terhadap ROA hanya $3,2 \%$. Hal ini memiliki makna bahwa perputaran modal kerja perusahaan rendah menandakan ketidak 
mampuan manajemen perusahaan dalam mengelola modal kerjanya, sehingga menyebabkan rendahnya pengaruh terhadap ROA.

e. Perputaran kas, perputaran piutang, perputaran persediaan, dan perputaran modal kerja tidak berpengaruh signifikan terhadap return on asset. Dari hasil uji secara simultan nilai signifikansinya berada di atas 0,05 yaitu 0,632 , yang

\section{REFERENSI}

Brigham, E. F., \& Houston, J. F. (2011). Essentials of Financial Management (11th ed.). Salemba Empat.

Canizio, M. A. (2017). Pengaruh Perputaran Kas, Perputaran Piutang, Perputaran Persediaan Terhadap Profitabilitas Pada Supermarket Timor Leste. E-Jurnal Ekonomi Dan Bisnis Universitas Udayana, 10, 3527-3548.

Ghozali, I. (2016a). Aplikasi Analisis Multivariate dengan Program IBM SPSS 23. Badan Penerbit Universitas Diponegoro.

Ghozali, I. (2016b). Aplikasi Analisis Multivariate Dengan Program IBM SPSS 23. Badan Penerbit Universitas Diponegoro.

Hanafi, M. M. (2016). Manajemen Keuangan (2nd ed.). BPFE Yogyakarta.

Kasmir. (2017). Analisis Laporan Keuangan. PT Rajagrafindo Persada.

Keown, A. J., Martin, J. D., Petty, J. W., \& Scott Jr, D. F. (2010). Financial Management (10th ed.). Indeks.

L. Rajagukguk, S. Dini, S. Silalahi, E. Marpaung, D. S. S. (2020). Pengaruh Perputaran Kas, Persediaan, Piutang, Modal Kerja Terhadap Profitabilitas Perusahaan. Jurnal Ekonomi, 25(2), 270. https://doi.org/10.24912/je.v25i2.6 menunjukkan bahwa $\mathrm{H}_{0}$ diterima dan $\mathrm{H}_{1}$ ditolak. Artinya bahwa Perputaran kas, perputaran piutang, perputaran persediaan, dan perputaran modal kerja tidak maksimal, dan hanya $27,8 \%$ dalam mempengaruhi return on asset dan $72,2 \%$ dipengaruhi oleh faktor lain yang tidak diteliti.

Mardiah, M., \& Nurulrahmatiah, N. (2020). Pengaruh Perputaran Modal Kerja dan Perputaran Piutang Terhadap Profitabilitas Pada PT. Hanjaya Mandala Sampoerna Tbk. Jurnal Ilmiah Manajemen, XI(2), 97-102.

Munawir. (2004). Analisis Laporan Keuangan. Liberty Yogyakarta.

Nurafika, R. A. (2018). Pengaruh Perputaran Kas, Perputaran Piutang, Perputaran Persediaan Terhadap Profitabilitas Pada Perusahaan Semen. JURNAL AKUNTANSI DAN BISNIS : Jurnal Program Studi Akuntansi, 4(1). https://doi.org/10.31289/jab.v4i1.1 532

Priyatno, D. (2012). Cara Kilat Belajar Analisis Data dengan SPSS 20. Andi OFfset.

Sartono, A. (2016). Manajemen Keuangan Teori dan Aplikasi (4th ed.). BPFE Yogyakarta.

Sugiyono. (2014). Metode Penelitian dengan pendekatan Kuantitatif, Kualitatif dan $R \& D$. Alfabeta Bandung.

Sugiyono. (2018). Metode Penelitian Kuantitatif, Kualitatif, dan $R \& D$. Alfabeta Bandung.

Suryanto, D. (2020). JUSIE. V, 22-35. www.idx.co.id. (n.d.). Bursa Efek Indonesia. 